報 文

\title{
嫌気一好気式高濃度活性污泥法による窒素除去法 (2)
}

\author{
——理論，設計，実施例——
}

\section{5. 嫌気一好気式高濃度活性污泥法の実施例}

本法の実用化には, 流入下廃水の水質, 水量変動や 水温変動のある実際条件下で，净化機能を把握する必 要がある.そこで, 容量 $2.27 \mathrm{~m}^{3}$ の FRP 製実用施設を 建造し, S-下水処埋場沈砂池流出水を処理対象下水 として用い本法の実用試験を約 3 年間にわたって行っ た.

\section{一実施設の設計一一}

ベンチスケールの実験で得られた処理成績をもとに 表 3 の設計条件で実施設を設計した。

表 3 実施設の設計条件

\begin{tabular}{|ll|r|}
\hline 流入下水量 & $(\mathrm{Qs})$ & $2.5 \mathrm{~m}^{3} /$ 日 \\
流入水 $\mathrm{CDOcr}$ 濃度 & $\left(\ell_{\mathrm{S}}\right)$ & $250 \mathrm{mg} / \ell$ \\
流入水全窒素濃度 & $\left(\mathrm{N}_{\mathrm{Ts}}\right)$ & $30 \mathrm{mg} / \ell$ \\
処理水全窒素濃度 & $\left(\mathrm{N}_{\mathrm{T} 1}\right)$ & $6 \mathrm{mg} / \ell^{*}$ \\
槽内活性污泥濃度 & $\left(\mathrm{S}_{1}=\mathrm{S}_{2}\right)$ & $5,000 \mathrm{mg} / \ell$ \\
好気槽内 $\mathrm{TKN}$ 濃度 & $\left(\mathrm{N}_{\mathrm{k} 2}\right)$ & $2 \sim 3 \mathrm{mg} / \ell$ \\
\hline
\end{tabular}

*全窒素除去率 $80 \%$ を仮定

ベンチスケールの実験結果から, 本法で全窒素除去 率80\%を得るには, 本法の $\mathrm{COD}_{\mathrm{Cr}}-\mathrm{SS}$ 負荷量 $\left(\mathrm{L}_{\mathrm{o}}=\right.$ $\mathrm{Q}_{\mathrm{s}} \ell_{\mathrm{s}} / \mathrm{SV}_{\mathrm{T}}$ ）は全酸化負荷域の 0.075 1/日程度に維 持しなりればならないてとが明らかになっているので(1), 全反応槽容量 $\mathrm{V}_{\mathrm{T}}$ は次式から求められる。

$$
\mathrm{V}_{\mathrm{T}}=\frac{\mathrm{Q}_{\mathrm{s}} \cdot \ell_{\mathrm{s}}}{\mathrm{S} \cdot \mathrm{L}_{\mathrm{o}}}=\frac{2.5 \times 250}{5,000 \times 0.075}=1.67 \mathrm{~m}^{3}
$$
少し安全を見込んで $\mathrm{V}_{\mathrm{T}}=1.7 \mathrm{~m}^{3}$ とした。

次に, 前報(2)の 4 項に示した設計式と $\mathrm{k}_{\mathbb{1}}, \mathrm{k}_{\mathrm{k} 2}^{\prime}$ 值を用いて， 好気槽容量 $\left(\mathrm{V}_{2}\right)$ 之嫌気槽容量 $\left(\mathrm{V}_{1}\right)$ を計算すると 次のようになる。図-7, 図-8で求めた合成下水，合成

*大阪大学工学部環境工学科 教授

** 大阪大学工学部環境工学科 助手

$0388-9459 / 83 / 0400-0208 \$ 02.00 / 0 € 1983$
橋 本 奨* ・古川憲 治 $* *$

し尿にかかわる $\mathrm{k}_{\mathrm{T} 1}, \mathrm{k}_{\mathrm{K} 2}^{\prime}$ 值は実際都市下水のそれらと 異るはずである．しかし，合成下水と都市下水にかか わる両者の $\mathrm{k}_{\mathrm{T} 1} / \mathrm{k}^{\prime} \mathrm{K}_{2}$ 比は大きく変らないと考えられる ので, (37) 式から $\mathrm{V}_{2} / \mathrm{V}_{1}$ 比は求められる.

$\frac{\mathrm{V}_{2}}{\mathrm{~V}_{1}}=-\frac{\mathrm{k}_{\mathrm{T} 1} \mathrm{~S}_{1}}{\mathrm{k}_{\mathrm{K} 2}^{\prime} \mathrm{S}_{2} \mathrm{~N}_{\mathrm{K} 2}}$

上式に，図-7の合成下水で求めた $\mathrm{k}_{\mathrm{T} 1}=0.040$ (1/月) $\mathrm{k}^{\prime} \mathrm{k}_{2}=0.0121(1 / \mathrm{mg} / \mathrm{l} /$ 日 $)$ の值之, 表 3 の設計条 件を代入すると， $\mathrm{V}_{2} / \mathrm{V}_{1}$ 比は次のようになる。

$\frac{\mathrm{V}_{2}}{\mathrm{~V}_{1}}=\frac{0.040}{0.0121 \times(2 \sim 3)}=1.67 \sim 1.10$

ここでは，設計の容易さを考えて，嫌気槽容量に安全 を見込み， $\mathrm{V}_{2} / \mathrm{V}_{1}=1.0$ つまり, $\mathrm{V}_{1}=\mathrm{V}_{2}=0.85 \mathrm{~m}^{3}$ と した。

嫌気槽の擋拌は，完全な密閉之嫌気維持に留意し， 経済的と考えられる嫌気ガスによる循環方式とした．

沈殿池容量は, 本法が高污泥濃度（5,000 10,000 $\mathrm{mg} / \ell$ ) を採用しているととを考虑し, 滞留時間を標 準的な 3.0 時間よりあ長くとり 4.7 時間として $0.49 \mathrm{~m}^{3}$ とした，更に又，嫌気槽污泥の沈降性を改善するため に，嫌気槽之沈殿池の間に，容量 $0.08 \mathrm{~m}^{3}$ の再曝気槽 を設けた。

以上，各槽の設計容量を表 4 亿示した. また，図-10 表 4 実施設の槽容量

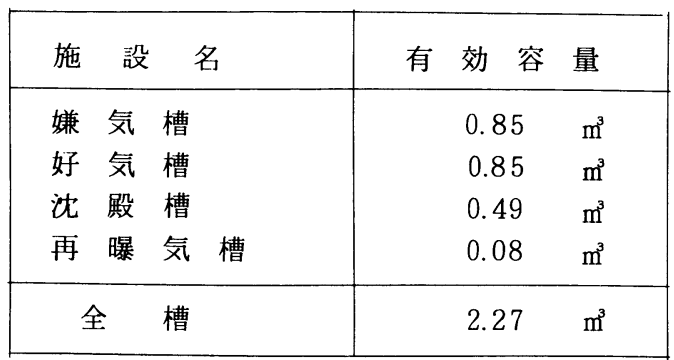


と図-11に建造した実施設の平面図と断面図を示した。 写真-1には，実施設の全景写真を示した。

\section{一試験方法—}

\section{。実施設の運転操作}

$\mathrm{S}$-下水処理場の沈砂池流出下水を水中ポンプで 5 分間隔に汲上げ，スクリーンで下水中の樉雑物を除去 した後, 容量 $0.17 \mathrm{~m}^{3}$ の眝留槽に送水した。（昭和53年 5 月以降は, 乙の貯留槽にかえ, 容量 $1 \mathrm{~m}^{3}$ の最初沈殿 池に送水した。）嫌気槽污泥混合液は，沈殿池で上澄 処理水と沈殿污泥に分離され，乙の沈殿污泥は種污泥 として, 流入下水量の $3 \sim 5$ 倍量で好気槽に返送循環 される.

\section{。污泥の馴養}

昭和52年 7 月 8 日 S - 都市下水処理場の返送污泥を 種污泥として実施設に投入し，COD cr－SS負荷を約 $0.151 /$ 日にとり,嫌気槽も好気状態に維持しながら, 全酸化処理方式で污泥の馴養を計った.馴養開始 17 日後 に処理水に $\mathrm{NO}_{3}-\mathrm{N}$ が検出されるようになり, 硝化反応の 進行が認められた. 馴養開始21日後には姏理水 $\mathrm{NH}_{4}-\mathrm{N}$ $1.0 \mathrm{mg} / \ell$ 以下となり, 硝化反応が完全となった.そこで 嫌気槽を完全密封して馴養を続けた。約 1 ケ月の馴養

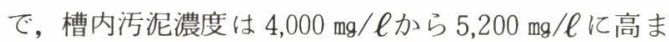
り, 馴養開始時の SVI が 200 から約 100 にまで低下し 同時にTotal - N除去率も60\%を超え，馴養 1 ケ月後

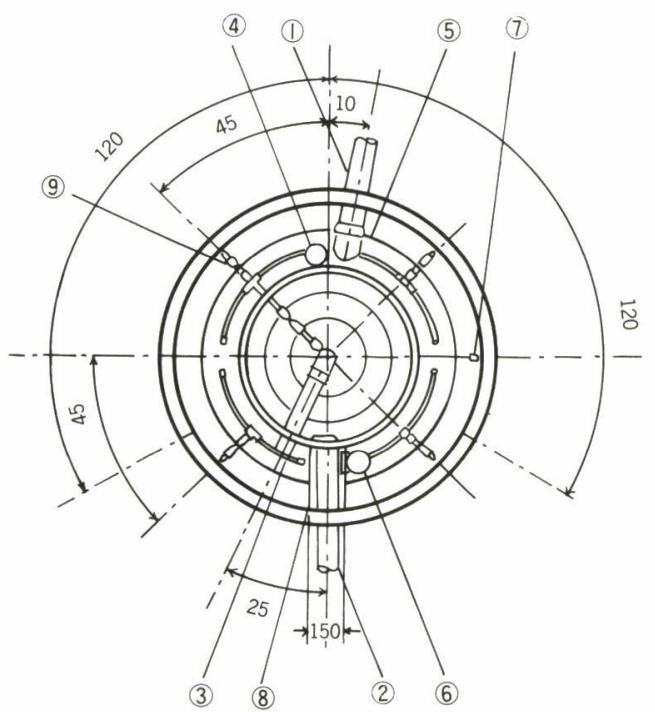

図-10 実施設平面図
(1)廃水導入管
(2) 処理水流出管
(3) 污泥返送管 (4) 好気槽 $\rightarrow$ 嫌気槽移流管 (5)循環仕切り壁 (6) 嫌気槽 $\rightarrow$ 再曝気槽移流管 (7) 嫌気吸引管 (8) 再曝気槽仕切壁

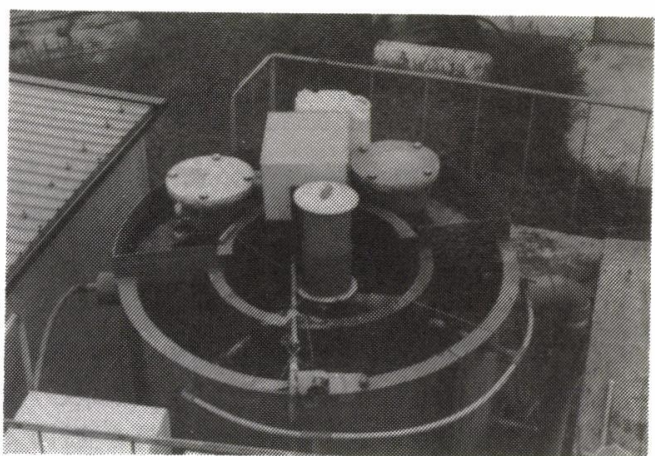

写真 1 実施設の全景

で「嫌気一好気式高濃度活性污泥法」の成立が認めら れた。

\section{。試料採取と分析}

流入水と処理水の試料は，24時間定量ポンプで連続 採取した混合試料とした，夏季には，腐敗等による水 質変化を防止するために, 試料に濃硫酸を $0.1 \%$ 添加 した。好気槽水質は, 好気槽内にフィルタ・セパレー夕 （フィルター面積 $38 \mathrm{~cm}^{2}$ ）を設置し, 固液分離された上 澄み液を定量ポンプで連続採取して得た混合試料で代 表させた。

表 5 には，3 个年にわたる実用化試験の年度別の実 験目的と実験方法の概要を一括表示した。

\section{— 試験成績——}

有機物－SS 負荷を低く維持する全酸化処理法で実 施設を運転した。3 ケ年にわたる実試験でかなり長期

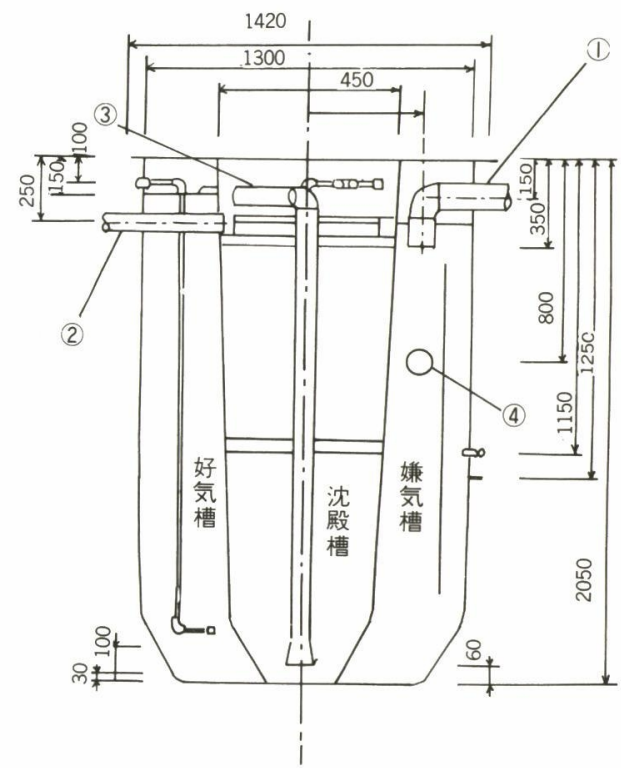

図-11実施設断面図（単位は $\mathrm{mm}$ ) 汴中の番号は，図-10 と同じ 
表 53 ケ年にわたる実用化試験の年度別試験目的と試験方法

\begin{tabular}{|c|c|c|}
\hline 年度 & 試 験 目 的 & 試＼cjkstart験＼cjkstart方 \\
\hline 52 & $\begin{array}{l}\text { 実施設で実廃水を用いて, Tota l - N , } \\
\text { CODcr 除去率に及ぼす諸因子を検討し， } \\
\text { 本法の最適運転法を明らかにする. }\end{array}$ & $\begin{array}{l}\text { 全酸化処理方式で槽内活性污泥濃度を出来る限り } \\
\text { 高める. 循環比, CODcr - SS 負荷を種々変化 } \\
\text { させる. 冬季, 好気槽に } \mathrm{NaOH} \text { 補填する. }\end{array}$ \\
\hline 53 & $\begin{array}{l}\text { 新設した最初沈殿池の流出水を処理対象 } \\
\text { 下水として処理を行う. 流入下水 } \mathrm{C} / \mathrm{N} \\
\text { 比の窒素除去率に及ぼす影響を検討する. }\end{array}$ & $\begin{array}{l}\text { 流入下水の } \mathrm{C} / \mathrm{N} \text { 比を高めるために, 廃糖密酵母 } \\
\text { 醗酵廃液を流入下水に定量補填する. }\end{array}$ \\
\hline 54 & $\begin{array}{l}\text { 実施設の処理データを動力学的に解析し, } \\
\text { 実廃水についての } \mathrm{k}_{\mathrm{T} 1}, \mathrm{~K}_{\mathrm{k} 2}^{\prime} \text { 値を求めて, } \\
\text { 種々考察する. }\end{array}$ & $\begin{array}{l}\text { 流入下水にウィスキー蒸留廃液を補填し, 流入下 } \\
\text { 水の } \mathrm{C} / \mathrm{N} \text { 比を適正な範囲に維持する. 動力学解 } \\
\text { 析ができ得るように, 好気槽水質をフィルタ・セ } \\
\text { パレータで正確に連続採取して, 分析する. }\end{array}$ \\
\hline
\end{tabular}

間安定して処理できた期間を試験Na別にして処理成績 を表 6 に一括表示した。

\section{。昭和52年度の試験成績}

試験 1，試験 2 の Total-Nは，前者では平均 $75.4 \%$ 後者では平均 $76.9 \%$ 除去された。試験 2 の $\mathrm{COD}_{\mathrm{Cr}}-$ SS負荷が 0.157 1/日と高くなっているが, てれは槽 内污泥濃度を高めるために，意図的に $Q_{\mathrm{S}}$ 值を高めた ためである。

試験 3 では, $r=4.0$, 処理温度 $13^{\circ} \mathrm{C}$ で 比較的安定 した処理が可能であった。しかし，昭和52年 1 月 10 日 頃, 処理温度が $10^{\circ} \mathrm{C}$ 以下になると, 適正な循環比と $\mathrm{C}$ $\mathrm{OD}_{\mathrm{cr}}$-SS 負荷量を維持しているにもかかわらす，好 気槽での污泥混合液の発泡があり, Total-Nの除去率 は著しく低下した。乙の時, 好気槽の $\mathrm{pH}$ は 5.0 以下, アルカリ度は $10 \mathrm{mg} / \ell$ 以下であった。 そこで，好気槽 に NaOHを50 g/日の割合で補填したとてろ, 発泡が なくなると同時に, Total-N除去率も試験 4 に示した ように，約70\%まで回復した。

昭和53年 1 月, 2 月期の試験デー夕を用いて, 好気 槽への NaOH補填有無の両者の場合における全槽のTotal-N-SS除去速度 $\left\{Q_{\mathrm{s}}\left(\mathrm{N}_{\mathrm{Ts}}-\mathrm{N}_{\mathrm{T} 1}\right) / \mathrm{SV}_{\mathrm{T}}\right\}$ と処理温度 の関係を調べ，図-12 の結果を得た $\mathrm{NaOH}$ の補填がな ければ $10^{\circ} \mathrm{Cを}$ 境として全槽のTotal- $N$ - SS 除去速度

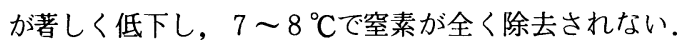
しかし， $\mathrm{NaOH}$ を補填すると，全槽のTotal $-\mathrm{N} \times \mathrm{SS}$ 除 去速度が高まり, 窒素の全く除去されなくなる温度は $4^{\circ} \mathrm{C}$ なり, 先の $\mathrm{NaOH}$ 無補填の $7 \sim 8{ }^{\circ} \mathrm{C} よ り$ 屯更に 低くなるので，本法の運転操作面で有利になることが 判った.
昭和52年度の SVI 值は約85〜 150 と年間を通じて良 好で, 冬季においてもバルキングは観察されなかった。

\section{○昭和 53 年度の試験成績}

本実施設は, 当初加ら浮上分離型嫌気一好気式高濃

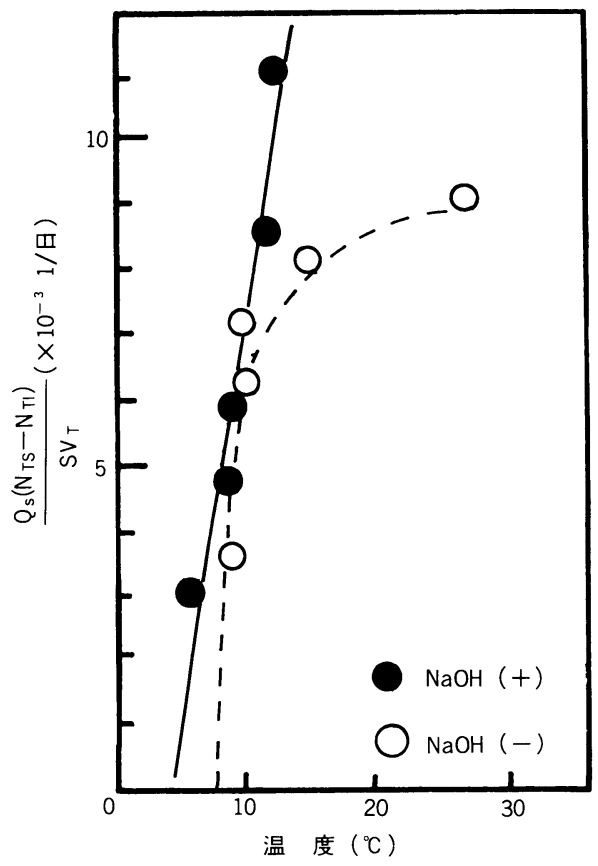

図-12 全槽のTotal $-\mathrm{N}-\mathrm{SS}$ 除去速度に 及ぼす温度の影響 データ設定条件

$$
\begin{aligned}
& \mathrm{COD}_{\mathrm{cr}}-\mathrm{SS} \text { 負荷量 }=0.08 \sim 0.11 \mathrm{1} / \text { 日 } \\
& \text { Total }-\mathrm{N}-\mathrm{SS} \text { 負荷量 }=0.010 \sim 0.0141 / \text { 日 } \\
& =\text { 約 } 4.0
\end{aligned}
$$

流入下水 $\left(\mathrm{COD}_{\mathrm{c} \mathrm{r}} /\right.$ Total $\left.-\mathrm{N}\right)=7 \sim 10$ 


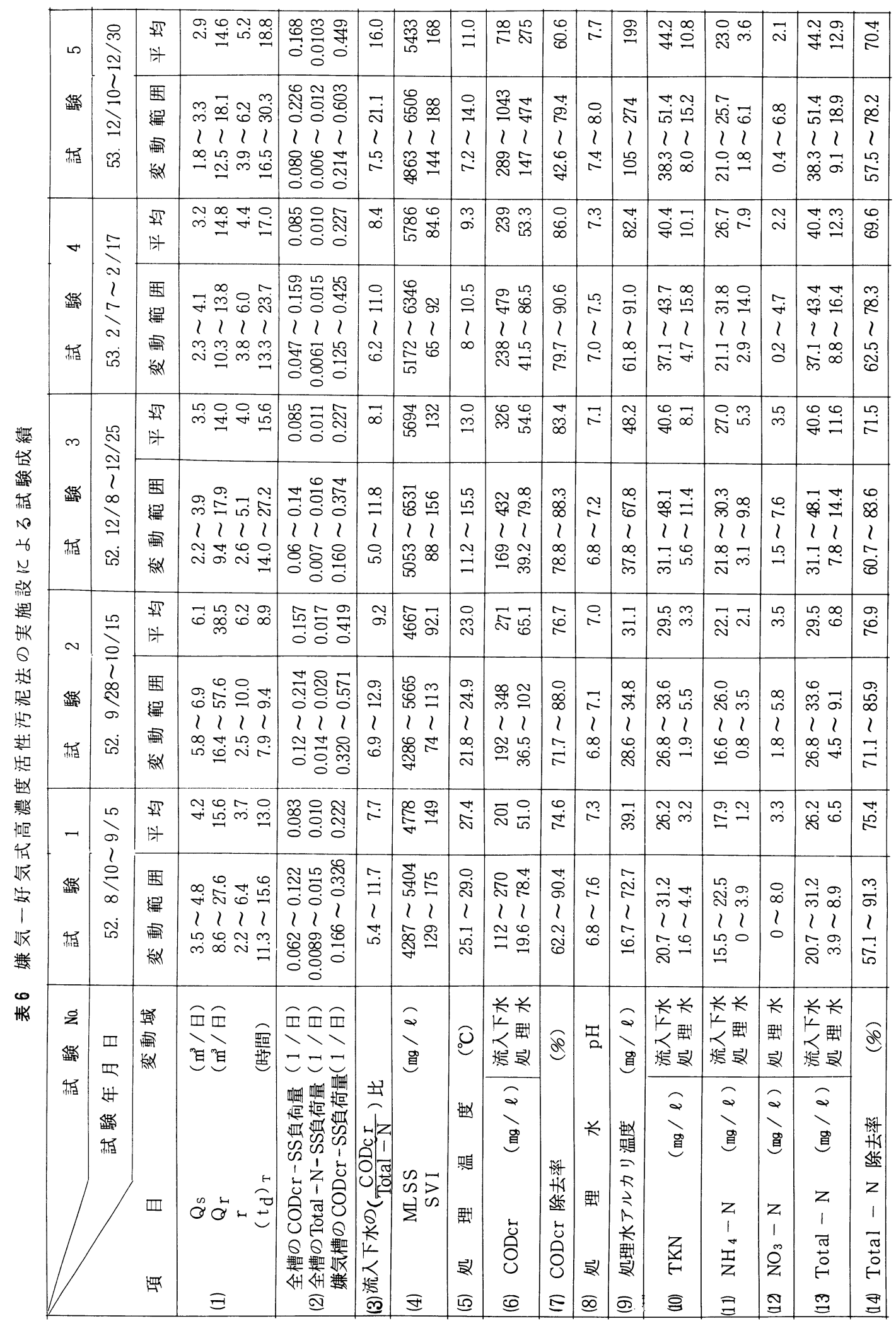




\begin{tabular}{|c|c|c|c|c|c|c|c|c|c|c|c|c|c|c|c|c|}
\hline$\exists$ & 0 & $\begin{array}{l}\text { 霖 } \\
\text { 斗 }\end{array}$ & 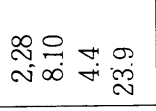 & 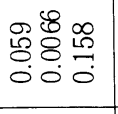 & $\ddot{\sigma}$ & 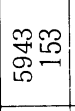 & $\hat{n}$ & 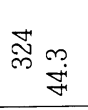 & $\begin{array}{l}n \\
\infty \\
\infty\end{array}$ & $\stackrel{\Upsilon}{\sim}$ & $\begin{array}{l}0 \\
\infty\end{array}$ & $\begin{array}{ll}m & 0 \\
\stackrel{0}{\infty} & 0\end{array}$ & ๗ె. & 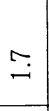 & $\begin{array}{l}m \\
\stackrel{n}{\infty} \infty\end{array}$ & $\begin{array}{l}\infty \\
\infty \\
\infty\end{array}$ \\
\hline 㮌 & 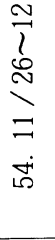 & $\begin{array}{l}\text { 西 } \\
\text { 哃 } \\
\text { 雷 } \\
\text { 战 }\end{array}$ & 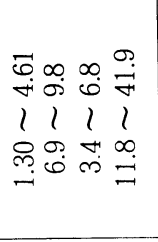 & 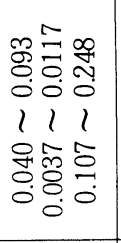 & $\begin{array}{l}0 \\
\stackrel{0}{1} \\
1 \\
m \\
\end{array}$ & 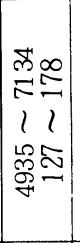 & 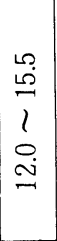 & 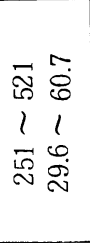 & \begin{tabular}{l}
$\infty$ \\
$\infty$ \\
$\infty$ \\
1 \\
\multirow{2}{\sigma}{}
\end{tabular} & $\begin{array}{l}5 \\
1 \\
0 \\
0 \\
0\end{array}$ & $\frac{\infty}{1}$ & $\begin{array}{cc}\vec{\nabla} & 0 \\
\overrightarrow{+} & \infty \\
l & 1 \\
\dot{n} & \infty \\
\dot{m} & \infty\end{array}$ & 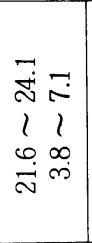 & $\begin{array}{l}m \\
\infty \\
1 \\
0\end{array}$ & 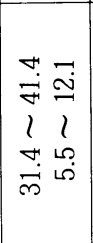 & $\begin{array}{l}0 \\
\dot{8} \\
1 \\
\infty \\
\infty \\
0\end{array}$ \\
\hline$\subseteq$ & $\stackrel{\llcorner 0}{=}$ & $\begin{array}{l}\text { 昰 } \\
\text { 放 }\end{array}$ & 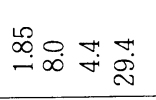 & 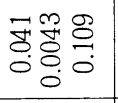 & $\stackrel{\infty}{\infty}$ & 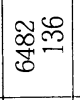 & $\underset{\infty}{\infty}$ & $\stackrel{\sim}{\sim} \underset{\sim}{\mathscr{H}}$ & $\underset{\infty}{\overleftarrow{\pi}}$ & $\stackrel{\circ}{\sim}$ & $\stackrel{N}{\infty}$ & $\begin{array}{ll}\stackrel{\sigma}{p} & \sigma \\
\ddot{m} & \sim\end{array}$ & $\begin{array}{ll}\infty & 0 \\
& 0\end{array}$ & $\stackrel{\bullet}{\sigma}$ & 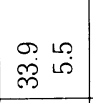 & $\begin{array}{l}\infty \\
\infty \\
\infty\end{array}$ \\
\hline 稆 & $\begin{array}{l}\overline{7} \\
1 \\
m \\
\overline{-} \\
0 \\
\text { षi }\end{array}$ & 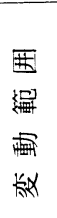 & 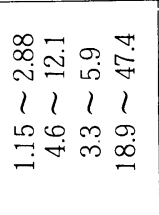 & 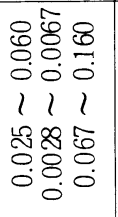 & 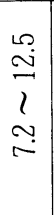 & 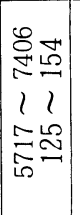 & 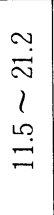 & 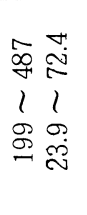 & $\begin{array}{l}F \\
\text { के } \\
1 \\
0 \\
\infty \\
\infty\end{array}$ & $\begin{array}{l}2 \\
1 \\
\vdots \\
0\end{array}$ & 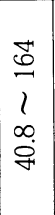 & 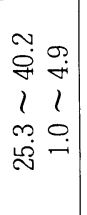 & $\begin{array}{ll}m & \\
\infty & 7 \\
N & m \\
1 & l \\
0 & 0 \\
0 & 0\end{array}$ & $\begin{array}{c}\tilde{1} \\
\infty \\
1 \\
0 \\
0\end{array}$ & 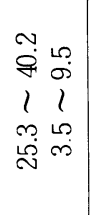 & $\begin{array}{l}m \\
\infty \\
1 \\
0 \\
\infty \\
\infty\end{array}$ \\
\hline$\sigma$ & $\stackrel{\infty}{=}$ & $\begin{array}{l}\text { 霖 } \\
4\end{array}$ & 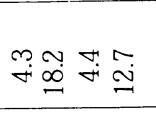 & 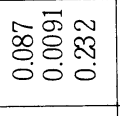 & $\mathscr{\sigma}$ & 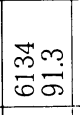 & 吕 & $\stackrel{\sim}{\stackrel{\sim}{*}}$ & ঙ্ড & $\stackrel{\Upsilon}{\Upsilon}$ & $\underset{ن}{0}$ & $\stackrel{\substack{\infty \\
\sim}}{\sim}$ & $\begin{array}{l}\infty \\
\infty \\
\infty\end{array}$ & $\hat{m}$ & 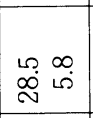 & $\begin{array}{l}\infty \\
\dot{\sigma}\end{array}$ \\
\hline 桰 & $\begin{array}{l}2 \\
\frac{1}{2} \\
\frac{1}{6}\end{array}$ & $\begin{array}{l}\text { 西 } \\
\text { 㹂 } \\
\text { 笽 } \\
\text { 瓶 }\end{array}$ & 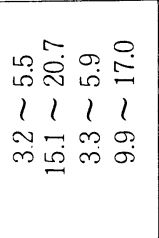 & 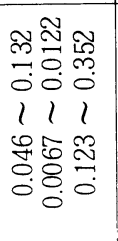 & 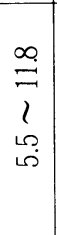 & 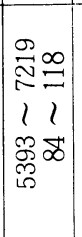 & $\begin{array}{l}0 \\
\stackrel{N}{N} \\
1 \\
\infty \\
\stackrel{N}{N}\end{array}$ & 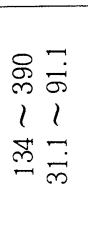 & $\begin{array}{l}8 \\
1 \\
0 \\
\frac{1}{6}\end{array}$ & $\begin{array}{l}\pi \\
1 \\
0 \\
0\end{array}$ & $\begin{array}{l}0 \\
= \\
1 \\
0 \\
m\end{array}$ & $\begin{array}{cc}0 & 0 \\
\text { mi } & + \\
1 & 1 \\
\dot{+} & 0 \\
\tilde{N} & 0\end{array}$ & 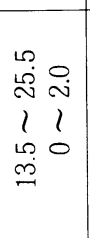 & \begin{tabular}{l}
$\infty$ \\
\multirow{1}{\infty}{} \\
1 \\
0 \\
0
\end{tabular} & 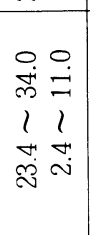 & $\begin{array}{c}0 \\
\text { a } \\
1 \\
m \\
\ddot{8}\end{array}$ \\
\hline$\infty$ & mి & $\begin{array}{l}\text { 䨛 } \\
\text { 米 }\end{array}$ & 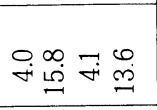 & 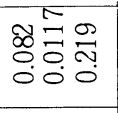 & $\Xi$ & 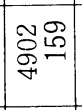 & 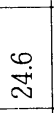 & ஸ્ง & $\stackrel{\sim}{\infty}$ & $\stackrel{?}{\sim}$ & ָุ & 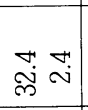 & $\stackrel{0}{\infty}$ & m & ָั & $\stackrel{v}{0}$ \\
\hline 紫 & $\begin{array}{l}0 \\
1 \\
-1 \\
0 \\
\text { एं }\end{array}$ & $\begin{array}{l}\text { 西 } \\
\text { 缉 } \\
\text { 雷 } \\
\text { 战 }\end{array}$ & 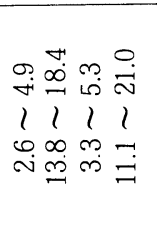 & 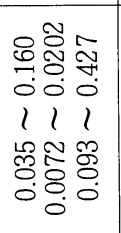 & $\frac{m}{2}$ & 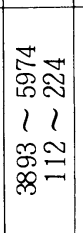 & 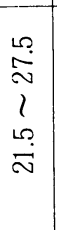 & 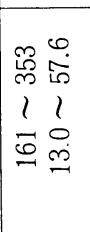 & 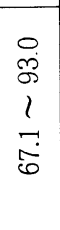 & $\frac{0}{2}$ & $\begin{array}{l}\ddot{1} \\
\infty \\
1 \\
\infty \\
\dot{m}\end{array}$ & 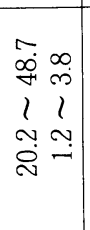 & 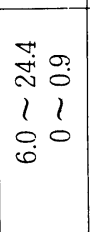 & $\begin{array}{l}\overrightarrow{0} \\
1 \\
-1\end{array}$ & 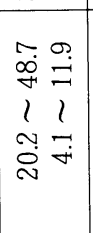 & 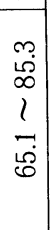 \\
\hline$\sim$ & ஜ & $\begin{array}{l}\text { 罚 } \\
\text { 米 }\end{array}$ & 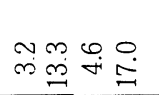 & 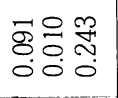 & $\infty$ & 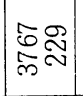 & $\stackrel{\oplus}{g}$ & 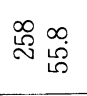 & $\stackrel{4}{\infty}$ & $\stackrel{0}{\sim}$ & $\ddot{n}$ & ஸ़ं ত্ণ & مَّما بّْا & $m$ & مْ & $\underset{\sim}{\stackrel{N}{N}}$ \\
\hline 㛎 & $\begin{array}{l}1 \\
1 \\
7 \\
10 \\
\text { एक }\end{array}$ & $\begin{array}{l}\text { 西 } \\
\text { 俋 } \\
\text { 雷 } \\
\text { 解 }\end{array}$ & 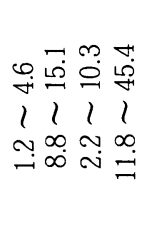 & 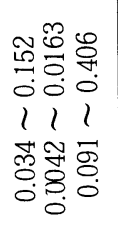 & 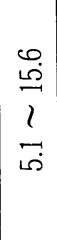 & 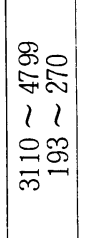 & $\begin{array}{l}\text { N } \\
\stackrel{1}{=}\end{array}$ & 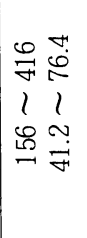 & $\begin{array}{l}m \\
\infty \\
\infty \\
1 \\
\infty \\
\infty \\
\infty\end{array}$ & $\begin{array}{l}-1 \\
1 \\
1 \\
0 \\
0\end{array}$ & $\begin{array}{l}\stackrel{2}{0} \\
1 \\
l \\
0 \\
\dot{m}\end{array}$ & $\begin{array}{cc}\stackrel{\sim}{*} & m \\
1 & 1 \\
0 & - \\
\stackrel{\sim}{N} & -\end{array}$ & $\begin{array}{ll}\text { N } & \text { N } \\
\text { N } & 0 \\
1 & 1 \\
0 & 0 \\
= & \end{array}$ & \begin{tabular}{l}
$\stackrel{\pi}{\pi}$ \\
1 \\
\multirow{2}{0}{}
\end{tabular} & 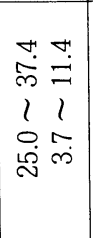 & $\begin{array}{l}r \\
\dot{6} \\
\infty \\
1 \\
0 \\
\ddot{B}\end{array}$ \\
\hline$\infty$ & $\stackrel{-}{\approx}$ & $\begin{array}{l}\text { 需 } \\
\text { 斗 }\end{array}$ & 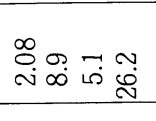 & 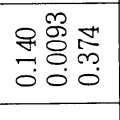 & $\underset{\Xi}{\stackrel{\Xi}{\Xi}}$ & 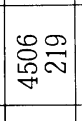 & $\stackrel{\infty}{0}$ & 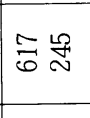 & 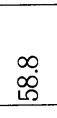 & $\stackrel{\Upsilon}{\sim}$ & $\stackrel{m}{-}$ & $\ddot{\forall}$ & 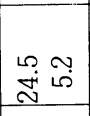 & 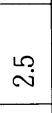 & 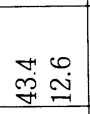 & $\stackrel{0}{E}$ \\
\hline 留 & $\begin{array}{l}l \\
\stackrel{2}{N} \\
\text { एं }\end{array}$ & 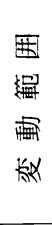 & 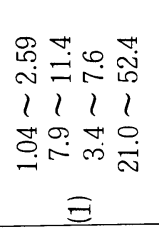 & 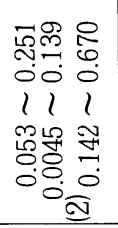 & $\begin{array}{l}\vec{\infty} \\
\frac{1}{7} \\
0 \\
\overline{0}\end{array}$ & 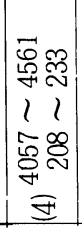 & 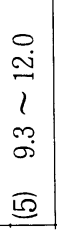 & 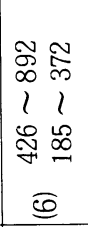 & $\begin{array}{l}\stackrel{L}{L} \\
\stackrel{2}{2} \\
1 \\
\stackrel{7}{9} \\
E\end{array}$ & 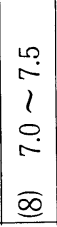 & 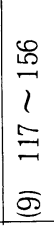 & 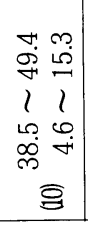 & 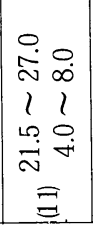 & $\begin{array}{l}70 \\
1 \\
+! \\
0 \\
\Xi\end{array}$ & 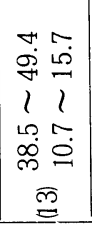 & 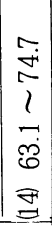 \\
\hline
\end{tabular}


度活性污泥装置と併設で, 実試験屯両者同時運転で行 った。 しかし, 浮上分離型嫌気一好気式高濃度活性污 泥処理装置の電磁弁部が, 沈砂池流出水中の異物（毛 髪や綿くす等）により閉塞されるトラブルが頻発し， 本実施設は運転に影響をうけた。そこで，スクリーン の後に，容量約 $1 \mathrm{~m}^{3}$ の最初沈殿池を設けた。ところが 流入下水の $\mathrm{C} / \mathrm{N}$ 比が昭和 52 年度に比して大巾に低下 し，約半年間にわたり，槽内污泥濃度や $\mathrm{Q} r$ 值を高め る等の種々の方策を試みたが，希望する70\%以上の To $\mathrm{tal}$-N 除去率を得ることができなかった。そこで， 流入下水の $\mathrm{C} / \mathrm{N}$ 比を高めるため, 流入下水に廃糖密 醅母醴酵廃液を添加した。試験 5, 試験 6 の成績に示す ように，乙の廃液の添加で流入水 $\mathrm{C} / \mathrm{N}$ 比は大巾に高ま り, Total - N 除去効率は約70\%に回復した. しかし, この廃液は, 生物難分解性の COD cr をかなりの量含 むという特性から, 処理水CODcrが $100 \mathrm{mg} / \ell$ 以下に 低下せす，廃糖密が本法の補填廃液として好ましくな いととが判った。 又, 乙の廃液の長期にわたる添加で 活性污泥の沈降性は徐々に悪化し, 添加開始約 2 ケ月 後に SV I 值は 200 を越え，沈殿池で污泥界面がみえる までに悪化した。

\section{。昭和 54 年度の試験成績}

昭和54年 4 月から, 廃糖密酵母醗䤉廃液の代りにサ ントリーウィスキー蒸留廃液を流入下水に添加し, 流 入下水の $\mathrm{C} / \mathrm{N}$ 比を高めた。

試験 7 試験11亿示したように，乙の廃液の添加で 流入下水のC $/ \mathrm{N}$ 比が昭和 52 年度と同程度に維持され， $\mathrm{COD}_{\mathrm{cr}}-\mathrm{SS}$ 負荷は $0.052 \sim 0.0911$ /日之低い值に維 持できた。 Total $-\mathrm{N}$ 除去率は, 平均約 $80 \%$ で, かなり 長期間安定して処理するてとができた.

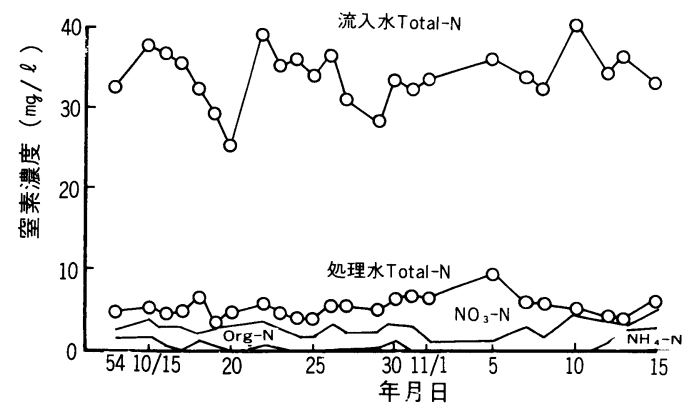

図-13 実施設による窒素処理挙動 実施設運転条件

CODcr - SS負荷量 $=0.0411 /$ 日 Total-N-SS負荷量 $=0.00431$ 日 循環比 $=3.4 \sim 6.8$

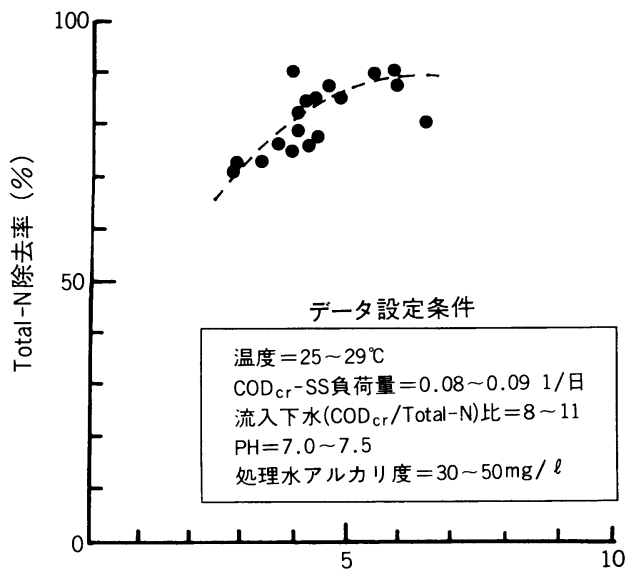

循環 比

図-14 夏季におけるTotal - N 除去率と循環比の関係

実施設による窒素処理挙動の一例として, 試験 10 を選び図-13 亿示した。図から，流入下水窒素濃度に 大きな変動があるにあかかわらす，処理水 Total - N濃 度はそ扎ほど变動せす，安定した窒素除去の行えるこ とが判る。

年度当初，廃糖密酵母醗酵廃液の添加の影響で，S V I > 200 であったが, ウィスキー蒸留廃液に切りか え，試験を進めるにつれ，污泥の凝集沈降性は徐々に 回復し, 試験 9 ではSVI=91.3にまで低下した。

\section{— 試験結果並びに考察 - -}

本法の窒素除去率は，(1)循環比，(2) COD $\mathrm{Cr}-\mathrm{SS}$ 負 荷量，(3)流入下水 $\mathrm{C} / \mathrm{N}$ 比，(4)処理温度に上り影響 を受ける。

\section{。窒素の除去率に及ぼす循環比 (r)の影響}

図-14 に夏季 $\left(25 \sim 29^{\circ} \mathrm{C}\right)$ における Total $-\mathrm{N}$ 除去率 と循環比（r) の関係を示した，全槽のCOD $r$ r $-S$ S負

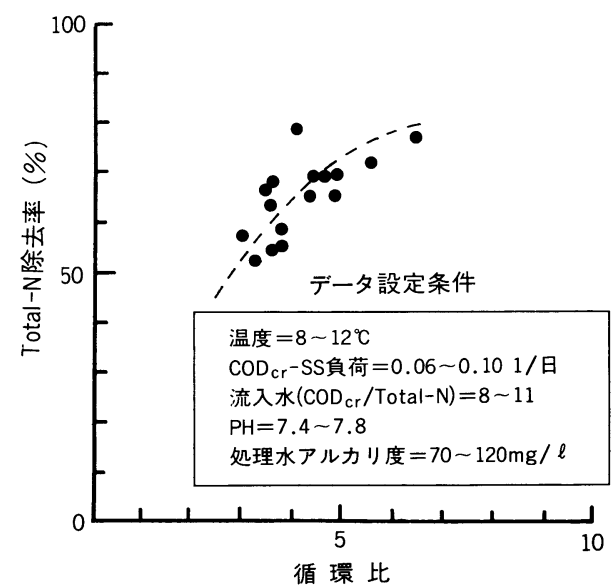

図-15 冬季におけるTotal - N 除去率と循環比の関係 
荷量, Total $-\mathrm{N}-\mathrm{SS}$ 負荷量, 流入水 $\mathrm{C} / \mathrm{N}$ 比, $\mathrm{pH}$, アル カ川度のCOD cr と Total - N の除去率に及ぼす影響をな くするため, 全槽の COD $\mathrm{r}$-SS 負荷量 $0.08 \sim 0.091$ /日, 全槽の Total $-\mathrm{N}-\mathrm{SS}$ 負荷量 $0.008 \sim 0.0111$ /日, 流 入下水 $\left(\mathrm{COD}_{\mathrm{cr}} / \mathrm{Total}-\mathrm{N}\right)$ 比 $8 \sim 11$, 処理水 $\mathrm{pH} 7$ $\sim 7.5$, 処理水アルカリ度 $30 \sim 50 \mathrm{mg} / \ell$ のデータを抽 出設定した。 Total $-\mathrm{N}$ 除去率は $\mathrm{r}$ に影響され，約 80 $\%$ 以上の除去率を達成するには, $\mathrm{r}$ を約 3.7 以上に 維 持する必要のあることが判った。

図-15 亿は, 冬季 $\left(8 \sim 12^{\circ} \mathrm{C}\right)$ 亿打ける Total一 $\mathrm{N}$ 除去 率とr の関係を示した. 前同様に, 図-15 亿示す設定条 件で実験デー夕を抽出設定した

夏季と同様に, Total $-\mathrm{N}$ 除去率はr けるが，その度合いは冬季の方が大きい，冬季は $\mathrm{r}$ を 大きくとっても，Total -N 除去率が80\% を越えるて とはなかった。

\section{。室素の除去率に及ぼす全槽のCODcr-SS負荷量 の 影響}

図-16には, 夏季 (処理温度 $25 \sim 30^{\circ} \mathrm{C}$ ) に扔ける Total - N 除去率と全槽の CODcr - SS 負荷量の関係 を示した。

Total $-\mathrm{N}$ 除去率は，全槽の COD cr - SS 負荷量の增 加につれて減少し, CODcr - SS 負荷量 $=$ 約 0.15 1 /日では, Total - N 除去率が約 $50 \%$ にまで減少し た. $80 \%$ 以上の Total $-\mathrm{N}$ 除去率を夏季, $\mathrm{r}=4.0$ の条件下で達成するには，本法の全槽のCO Dcr-SS 負荷量を0.085 1/日以下にとらなければならない.

図-17 には冬季（処理温度約 $10^{\circ} \mathrm{C}$ ）における Total -N除去率と全槽のCODcr-SS 負荷量の関係を示した。 Total $-\mathrm{N}$ 除去率は，夏季と同様の傾向を示したが, 全

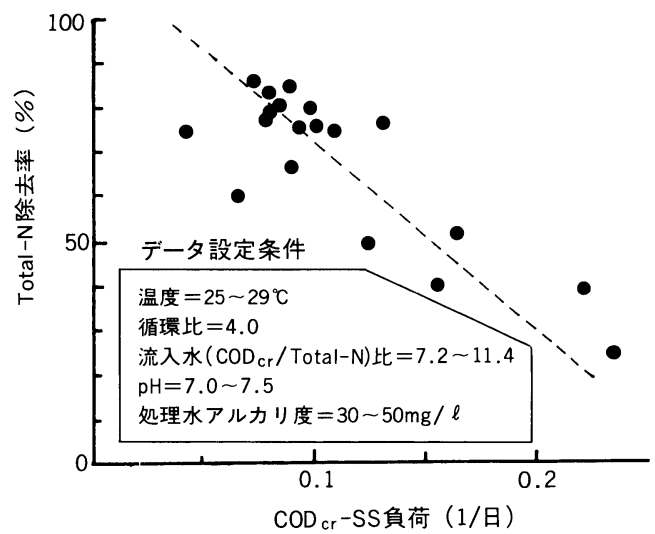

図-16 夏季におけるTotal - N 除去率に及ぼす COD cr - SS 負荷の影響

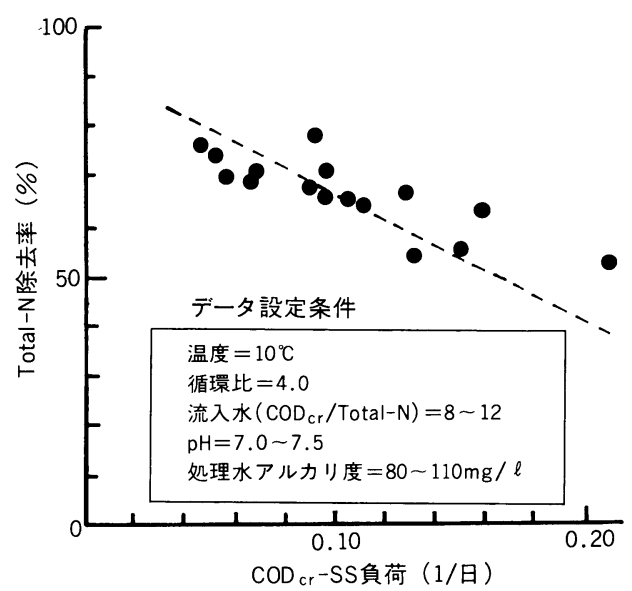

図-17 冬季に扔けるTotal一N除去率に及ぼす CODc r - SS 負荷の影響

槽の CODcr - S S 負荷量を低くとっても Total - N 除 去率が $80 \%$ を越えることはなかった。

\section{- Total-N除去率に及ぼす流入下水 $\left(C^{2} D_{c r} /\right.$ Total $-N)$ 比の影響}

流入下水の $\mathrm{COD}_{\mathrm{cr}} /$ Total-N比と Total-N除去率の関 係を調べるために，3 ケ年の試験デー夕から図-18 に 示す設定条件で実験デー夕を抽出設定し，図-18の結 果を得た。流入下水の $\left(\mathrm{COD}_{\mathrm{cr}} / \mathrm{Total}-\mathrm{N}\right)$ 比が 8.0 以上でTotal -N除去率は約 $80 \%$ 亿得られることが明 らかになった。

\section{。Total - N除去率に及ぼす温度の影響}

3 ケ年の実試験データから, 図-19 亿示す設定条件 で害験デー夕を抽出し, 処理温度と Total $-\mathrm{N}$ 除去率 の関係を調べ, 図-19を得た。

汹から判るように，本法のTotal一N

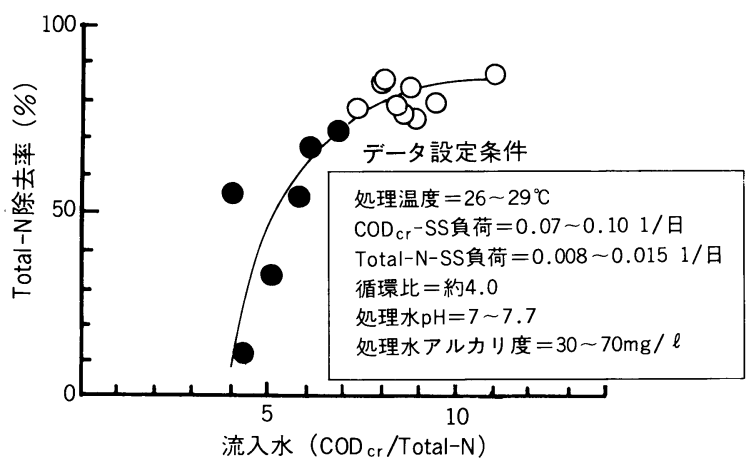

図-18 Total－N除去率に及ぼす流入下水（CODcr／ Total - N) 比の影響

○昭和 53 年度のデータ

昭和 52 年, 54 年度のデー夕 


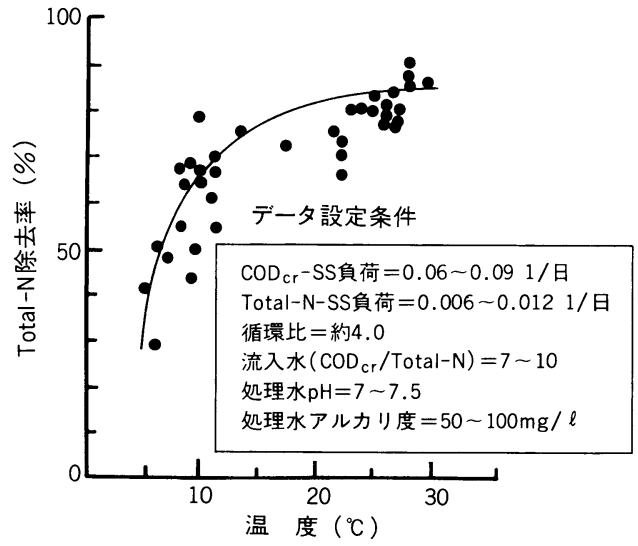

図-19 Total - N除去率と処理温度の関係

温度によってかなりの影響を受け，処理温度が $15^{\circ} \mathrm{C}$ 以 下になると，適正な運転を行っても Total一N 除去率 が80\%以下に著しく低下する，処理温度が $7{ }^{\circ} \mathrm{C}$ 以下に 低下すると Total -N除去率は約 $50 \%$ 以下に激減し, 嫌 気一好気式高濃度活性污泥法が成立しなくなることが よく判る。

以上, 容量 $2.27 \mathrm{~m}^{3}$ の実用施設による, $\mathrm{S}$ 一下水処理 場沈砂池流出水を処理対象廃水とした 3 个年にわたる 実試験結果から，本法の適正運転条件下における To－ $\mathrm{tal}$ - N除去率は, 循環比, CODcr $-\mathrm{SS}$ 負荷, 処理 温度によって大きく影響され, 夏季, 流入水( CODcr /N）比約 8.0 以上, 処理水 $\mathrm{pH} 7 \sim 7.5$, 処埋水 アル カリ度30 50mg / $\ell$ の条件下で約 $80 \%$ の Total $-\mathrm{N}$ 除 去率を達成するには, 循環比を約 4.0 以上, CODcr SS 負荷を約 0.08451 /日以下に維持しなければなら ないととが明らかとなった。しかし，処理温度が $15^{\circ} \mathrm{C}$ 以下になると，適正な運転操作を行っても Total一 N 除去率は約 $80 \%$ 以下になり，処理温度か $7{ }^{\circ} \mathrm{C}$ 以下にな ると, Total - N除去率は約 $50 \%$ 以下に激減した。

\section{6. ま と}

新しく考案したBiosorption 法と同一の流系図をも つ「嫌気一好気式高濃度活性污泥法」は，乙れまでに 開発されている下・廃水の窒素除去法とは污泥混合液 の流れと槽内污泥濃度の点で異なり, Barnard 法との比 較検討結果から，効率的に下・廃水中の窒素を脱窒除 去できる秀れた窒素除去法であることが明らかとなっ た。

次に，本法の嫌気槽における脱窒反応，好気槽にお ける硝化反応を動力学的に解析した. さらに, 図式決 定した嫌気槽における Total一N除去速度 $\left(\mathrm{k}_{\mathrm{T} 1}\right)$ ，好気
槽に打りる TKN除去速度恒数（ $\left.\mathrm{k}^{\prime}{ }_{\mathrm{k} 2}\right)$ を用いる本法の 設計式を誘導し，乙の設計式の適合性を合成下水の処 理実験によって検証した。

最後に，本法の3 ケ年にわたる実用試験成績につい て述へ，本法の Total 一 N 除去率に及ぼす因子の影響 を明らかにした。

\section{参 考 文 献}

（1）橋本, 古川：嫌気一好気式高濃度活性污泥法による 窒素除去, 下水道協会誌, Vol,14, No.152, 1(1977)

（2）橋本，古川：嫌気一好気式高濃度活性污泥法に上る 窒素除去法（1），環境技術。Vol１1，No. 12，5 (1982) 